\title{
Trade flow of manufacturing sector and foreign direct investment in ASEAN economic integration: the gravity model of trade
}

\author{
Diah Wahyuningsih
}

Faculty of Economics and Business, Universitas Trunojoyo Madura, Indonesia

Correspondence author email: diahwahyuningsih@yahoo.com

\begin{tabular}{|l|l|l|l|l|}
\hline DOI: & Received: & Revised: & Accepted: & Published: \\
10.22437/ppd.v8i6.10289 & 18.08 .2020 & 20.01 .2021 & 23.01 .2021 & 01.02 .2021 \\
\hline
\end{tabular}

\begin{abstract}
.
This study aims to determine the effects of ASEAN economic integration on the manufacturing sector's trade flow and foreign direct investment. This study using panel data regression. The results show that ASEAN economic integration affects trade in the manufacturing sector and foreign direct investment (FDI) in ASEAN member countries. The tariff elimination policy increased trade flows in the manufacturing sector and foreign direct investment. The variable of GDP has a positive and significant effect on the manufacturing sector's trade flows and foreign direct investment. Exchange rate variables have a negative and significant effect on trade flows in the manufacturing sector and foreign direct investment. Meanwhile, the distance variable negatively affects trade in the manufacturing sector, but it does not affect foreign direct investment.
\end{abstract}

Keywords: Economic integration, Foreign direct investment, Trading

JEL Classification: F1, F15, F21

\section{INTRODUCTION}

Economic globalization refers to the economy's integration process and is interrelated to the world economy nationally, regionally, and locally. Economic globalization covers the international flow of goods, services, and capital, tariff reduction, trade barriers, immigration, technology exchanges, and cross-border knowledge (Samimi \& Jenatabadi, 2014). Economic globalization is marked by the increasing welcomes to international trade, encouraging market competition that generates an efficient market by lowering production costs, driving creativity and innovation to create various products (Yulisa, 2017).

As part of a community globally, Indonesia is actively involved in various economic cooperations to open the access and remove the trade barriers (Damuri, 2006). Economic globalization implicates the international trade system of goods and services by eliminating trade barriers, such as tax reduction, trade quotas, as well as subsidy (Krugman \& Obstfeld, 2003). The trade barriers elimination induces industrial activity efficiency and opens access that can develop and expand the market. Thus, international trade flow in both goods and services is certainly developed.

Economic integration as discrimination elimination and trade independence is a form of policy transfer to joint institution. Economic integration has several forms referring to the degrees of integration, such as free-trade area, customs union, common market, economic union, and complete economic integration (Balassa, 1994). In 
Southeast Asia, the economic integration is in the form of the ASEAN Free Trade Area (AFTA), established in 1992. AFTA serves to eliminate trade barriers (such as trading cost and tariff) through the Common Effective Preferential Tariff (CEPT) scheme. Common Effective Preferential Tariff is an agreement to reduce the trading tariff and eliminate non-tariff among ASEAN nations. The eliminated tariffs are for the manufacturing and semi-manufacturing products, including capital materials and agricultural processing products. Common Effective Preferential Tariff in AFTA has reached $90 \%$ of the total mentioned products.

Furthermore, $65 \%$ of products listed in IL (Inclusion List) have been eliminated their tariffs. By eliminating the trade barriers, AFTA changes the ASEAN economy and creates a solid regional market. AFTA, as a gradual liberation trade agreement, has successfully reduced import tariffs of intra-ASEAN by $5 \%$ in fifteen years. However, tariff reduction only applies to specific products (as mentioned in the agreement). Nevertheless, it ensures that about $40 \%$ of products used are from ASEAN countries. Intra-ASEAN trade increases the involved countries' competition to secure the investment, production materials and capital, and trade in the region.

Ridhwan et al. (2015) argue that the more increasing the trade is, the more dynamic and multidimensional the involved countries are. Accordingly, in order to ensure economic development, FTA is needed as it eliminates trade barriers. Okabe (2015) mentions that FTAs should eliminate tariffs and liberate the service trade and Foreign Direct Investment (FDI). As an ASEAN member, Indonesia had experienced its impact, which is seen from the total trade development for the manufacturing sector (see Graph 1). The Indonesian trade intra-ASEAN had reached US\$250,817.2 million or $202 \%$ (from US\$ $118,109.1$ million to US\$ 118,109.1 million) in almost 15 years (2004-2018).

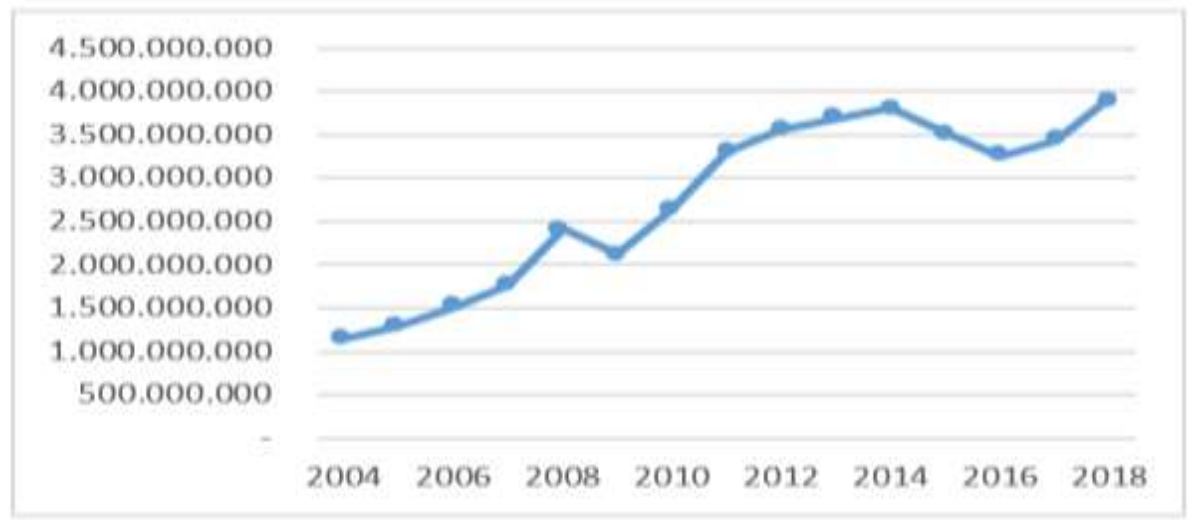

Figure 1. Development of total trade in the manufacturing sector intra-ASEAN $2004-2018$

Accordingly, Indonesia becomes the biggest manufacturing industry in ASEAN. This condition means that the national goals that develop the non-oil and gas industry by promoting the manufacturing industry are successfully engaged. Although the total Indonesian trade generally increased (2004-2018), in 2009, it declined due to the global economic crisis of 2008. This situation proves that the manufacturing sector can become the key factor of national economic development by inducing productivity and expanding the market. The manufacturing industry can add raw materials, absorb many laborers, and add national revenue (through tax and excise). Indonesian growth of Manufacturing Value Added (MVA) reached 4.84\% (the highest among ASEAN countries), and it is more than ASEAN MVA (4.5\%) (Baihaqi, 2018).

The increasing FDI certainly follows the increasing trade volume and market in ASEAN by the conditions of good systems in institutions, facilities, infrastructure, and 
low production cost (Kawai \& Naknoi, 2015). Krugman and Obstfeld (2003) define FDI or Foreign Direct Investment as the flow of international capital in which the founder (capital owner) establishes or/and expands one's business (company) in other countries. The prominent characteristics of FDI involve not only resource transferring but also power (capital) control. Unfortunately, Indonesia has hardly invited foreign investors compared to other ASEAN countries.

The gravity models are commonly utilized to analyze and assess trade flows in many studies. Besides, Evenett \& Keller (1998) mention three types of trade models to analyze the theoretical foundations of gravity equations, namely: (1) the Ricardian model to differentiate the technology across countries, (2) the H-O model to vary the endowment factors in the country, and (3) the Increasing Returns to Scale (IRS) model to measure the increasing returns at the firm level. According to Kepaptsoglou et al. (2010), the gravity model uses to describe and foresee the impacts of Free Trade Agreements (FTA) of the involved countries. FTA mostly eliminates tariffs, quotas, and other barriers (some or all) in the trade (among involved parties/ countries). The FTAs aim to increase trade of two or more countries due to unbinding or eliminating institutional and economic barriers.

Meanwhile, Topalova (2004) writes that reducing or loosening the trade protection can encourage productivity in private sectors, but not in the governmentowned or foreign company during the post-reformation period. Effendi (2014) finds that the FTA can develop the Indonesian trade performance among other related countries such as ASEAN, ASEAN+3, Uni Eropa, AS, and Australia. Moreover, he successfully used the gravity model to estimate and draw the Indonesian trade performance.

Helpman et al. (2004) state that companies participating in foreign markets are because they find an opportunity (foreign market), whether referring to resource availability or growth probability. Hence, they differ the actions into a) withdrawing from foreign markets, b) exporting exclusively to foreign markets, or c) investing in foreign production facilities to serve specific markets (FDI). Export-import has a lower fixed cost, while FDI has low variable costs. Thus, companies (capital owners) encouraged by the "trade-off proximity-concentration" relatively bend to export-import business than FDI. Although FDI reduces transportation costs, it has higher production costs (in terms of facilities). This study is different from previous studies, namely comparing the trade flow in the manufacturing sector with FDI in the presence of tariff reduction of $0-5$ percent during fifteen years of ASEAN economic integration. This study aims to determine the effects of ASEAN economic integration on the manufacturing sector's trade flow and foreign direct investment (FDI).

\section{METHODS}

This study uses annual data for the study period from 2004-2018 from 10 ASEAN countries. The data used in this study are secondary data obtained from various sources, namely Comtrade Database, World Bank, The Geographical Distance (GeoDist) Database.

This study employs descriptive analysis and data regression analysis of panel data. Descriptive analysis was employed to determine the development of the variable of the research model. In contrast, data regression analysis was employed to determine the independent variable's effect (ASEAN economic integration) on dependent variables (manufacturing sector trade and FDI).

Combining time-series and cross-section are panel data to find the bigger degree of freedom (Gujarati, 2015). Three models are used to estimate the model parameter, namely: Common Effect Model (CEM), Fixed Effect Model (FEM), and Random Effect 
Model (REM). CEM assumes no difference in both sector and time; thus, it only has a model for the whole observation (Baltagi \& Moscone, 2010). Fixed Effect Model or Least Square Dummy Variable (LSDV) model employs the dummy variable addition. LSDV model is used in linear regression parameter assumption with the least-squares method on the model. Meanwhile, REM carries several differences in individual characteristics and times or known as model error. Due to two elements (individual and time), REM combined both elements contributing to the 'error' as 'random error' (Baltagi, 2008).

The gravity model is a model used to explain two countries' trade flows unsolved by other economic theories. This model is a derivative theory of Newton's gravitational law stating that two objects' gravitational force is equal to their masses and inversely to their distance squared.

$$
F_{i j}=G \frac{M_{i} M_{j}}{D_{i j}^{g}}
$$

$F_{i j}$ is the gravitational force of object $i$ and $j ; G$ is the constant; $M_{i}$ and $M_{j}$ are the mass of objects $\mathrm{i}$ and $\mathrm{j}$, and $\mathrm{D}_{\mathrm{ij}}$ is the distance of two objects. Accordingly, Tinbergen (1962) applied this formula into an economic formula to calculate two countries' trade flows. Its variables are merged into an independent variable of Gross Domestic Product (GDP), namely trade flow and the two countries' distance. Hence, he hypothetically assumed that high GDP's and close-distance countries tend to open the market to each area (trading).

Besides, Anderson (1979) uses the gravitational equation by differentiating products with the Cobb-Douglass and CES (constant elasticity substitution) preference. Theory of gravity model from Heckscher-Ohlin (H-O model) and imperfect substitute theory into a mathematical equation which later used by (Krugman \& Obstfeld, 2003).

$$
T_{i j}=A \frac{Y_{i} Y_{j}}{D_{i j}^{\mathrm{g}}}
$$

$\mathrm{T}_{i j}$ is the gravitational force of object $i$ and $j$; $\mathrm{A}$ is the constant; $\mathrm{Y}_{i}$ and $\mathrm{Y}_{j}$ are the economic force of two countries $i$ and $j$, and $\mathrm{D}_{i j}$ is the distance of two countries.

Therefore, this study refers to prior researches Vahalík (2014) for determining the market size variables, Agnosteva et al. (2019) for determining the trade barriers variables, İncekara \& Ustaoğlu (2012) for determining tariff reduction variables, Zamroni (2005) for determining the FDI variables, and Silajdzic \& Mehic (2018) for determining economic openness. The gravity model equation is modified into two:

Equation 1

Trade $_{i t}=\beta_{0}+\beta_{1}$ GDP $_{i t}+\beta_{2}$ REER $_{i t}+\beta_{3} D I S T_{i t}+\beta_{4} D_{1} A F T A_{i t}+\beta_{5} O P E N_{i t}+\mu_{i t}$

Equation 2

$F D I_{i t}=\beta_{0}+\beta_{1} G D P_{i t}+\beta_{2} R E E R_{i t}+\beta_{3} D I S T_{i t}+\beta_{4} D_{1} A F T A_{i t}+\beta_{5} O P E N_{i t}+\mu_{i t}$

Trade $_{i t}$ is the export and import volume on the manufacturing sector of $i$ country to $j$ country in year $t$. FDI $i t$ is foreign direct investment obtained by $i$ and $j$ countries in year $t$. DGDP $i t$ is the market size of $i$ and $j$ countries in year $t$, REER $_{i t}$ is the exchange rate of $j$ country in year $t$; DIST $i t$ is transportation cost of $i$ country to $j$ country in year $t$; $\mathrm{D}_{1} \mathrm{AFTA}_{i t}$ is dummy variables of non-tariff; OPENit is the value of trade openness between $i$ and $j$ countries in year $t$; $\mu_{i}$ is error term; $\beta_{0}=$ constant, and $\beta_{0}=$ value of trade openness.

GDP represents the size of the two countries' economies, both in production capacity and market size. The market size variable is obtained from the average GDP of 
the two trading countries. The Real Effective Exchange Rate shows the purchasing power of domestic output by trading partners. This variable uses a proxy for exchange rate fluctuation obtained from the absolute difference in the currency value on US\$ and the exchange rate of the partnered country in US\$. The distance variable refers to the geographical distance of two countries. This study uses Indonesia's economic distance to the respective countries (ASEAN) as the GDP's partners.

$$
D I S T_{i j t}=\frac{\text { geograpgical distance } \times P D B_{f}}{\sum_{1}^{n}{ }^{P D B_{f}}}
$$

$\mathrm{PDB}_{f}$ is the GDP of $f$ trading partner; $i$ is Indonesia; $j$ is trading partner; and $t$ is the year (observed). DIST ${ }_{i j t}$ is the distance representing transportation cost. Economic integration is represented through tariff reduction in manufacturing sectors.

This study uses dummy variables to calculate the trade flow before and after implementing tariff reduction policy in manufacturing sectors. Moreover, a degree of openness is represented by economic integration, which employs the proxy ratio between the aggregate value of imports and exports and GDP.

\section{RESULTS AND DISCUSSION}

These calculations on the gravity model are utilized to determine the effect of gross domestic product (GDP), economic distance (DIST), real effective exchange rates (REER), economic openness (OPEN), and before and after the implementation of the AFTA on trade flow of manufacturing sector and FDI. Analysis with a gravity model begins by selecting an estimate, whether it is a common effect model, a fixed-effect model, or a random effect model. The estimation results use a static data panel with a gravity model.

Table 1. Chow test result

\begin{tabular}{lrrrr}
\hline \multirow{2}{*}{ Effects Test } & Equation 1 & & Equation 2 \\
& Statistic & Prob & Statistic & Prob \\
\hline Cross-section F & 88.564248 & 0.0000 & 4.313614 & 0.0000 \\
Cross-section Chi-square & 259.881672 & 0.0000 & 33.873187 & 0.0000 \\
\hline
\end{tabular}

The chow test result shows that the fixed effect model can better explain the model than pooled least square because the probability is accepted at a $95 \%$ level of confidence.

Table 2. Hausman test result

\begin{tabular}{lcccc}
\hline Test Summary & \multicolumn{2}{c}{ Equation 1 } & \multicolumn{2}{c}{ Equation 2 } \\
& Chi-Sq. Statistic & Prob & Chi-Sq. Statistic & Prob \\
\hline Cross-section random & 31.973525 & 0.0000 & 22.557351 & 0.0000 \\
\hline
\end{tabular}

The Hausman test result shows that the random effect model can better explain the model than fixed-effect because the probability is rejected at a $95 \%$ level of confidence. It indicates fixed effect model is better than compared random effect model.

Equation 1 (see Table 3) shows that GDP has a positive and significant effect on the trade flow of manufacturing sectors with a GDP coefficient of 0,97 . It means that if GDP increases by $1 \%$, the trade flow of manufacturing sectors will increase by $0,97 \%$, assuming all other variables remain constant.

The manufacturing sector trade flow is influenced by the income of its trading partners (countries). The bigger the size of the economy (in a country), the greater the trade transactions undertaken by that country. The country's economy's size represents the production capacity to produce manufacturing goods exported to the destination 
country for exporting countries. Whereas for importing countries, the country's economy's size represents the demand for imported manufactured goods. The greater the country's economy, the greater the ability to conduct trade in the manufacturing sector.

Table 3. Panel data regression result

\begin{tabular}{cccrc}
\hline Variable & \multicolumn{2}{c}{ Equation 1 } & \multicolumn{2}{c}{ Equation 2 } \\
& Coefficient & Prob. & Coefficient & \multicolumn{1}{c}{ Prob. } \\
\hline GDP & 0,968655 & $0,0000^{*}$ & 1,275509 & $0,0000^{*}$ \\
REER & $-0,033268$ & $0,0412^{* *}$ & $-1,759794$ & $-0,0006^{*}$ \\
DIST & $-0,304934$ & $0,0000^{*}$ & 1,614585 & 0,0992 \\
AFTA & 0,126586 & $0,0174^{* *}$ & 1,258973 & $0,0016^{*}$ \\
OPEN & 0,932453 & $0,0000^{*}$ & 1,099272 & $0,0242^{* *}$ \\
\hline R-squared & 0,997437 & \multicolumn{2}{c}{0,960592} \\
${ }^{*}$ Significant at $\alpha=1 \% ;{ }^{* *}$ Significant at $\alpha=5 \%$ &
\end{tabular}

Helpman \& Krugman (1989) state that economic equity and size have a positive relationship to trade. Countries that have similar (equivalent) economic size will trade in a larger manufacturing sector. It is driven by the influence of economic scale, which makes the country (exporter) produce goods for a larger market (where the demand for these goods is large) and will do the opposite (become an importer country) when the value of the desired goods is lower than the domestic price. There are three consequences of economic scale trading, namely: 1) the price (of goods) is lower than the autarchy in the trading country; 2) the number of companies that can survive (after trading) will decrease compared to autarchy; and 3) the sales of each company (which survive) will increase compared to autarchy (Krugman \& Obstfeld, 2003).

This analysis is in line with Wahyuningsih's (2011) research, which states that countries with similar (equal) economies will conduct greater intra-industrial trade. This result is in line with the research conducted by Paulus \& Michalíková (2014). They mention that the GDP of a country that engages in trading becomes the driving key to developing trading. Besides, Ugurlu \& Jindrichovska (2019) argue that the trading of two countries depends on their GDP's size. According to Frankel \& Romer (1999), countries that conducting trading are not affected by the level of people's income, government policies, or other factors that affect the income. Their opinion indicates that the trading rate (between two countries) is not influenced by geographical factors (the level of people's income) existing in that country. It is proved by Nasrullah et al. (2020) through their research on Chinese trading. They find that the increase in trading partners' population (importer countries) affects China's products (exporter country).

Real Effective Exchange Rates have a negative and significant effect on the trade flow of manufacturing sectors with a REER coefficient of $-0,03$. It means that if the exchange rate increases by $1 \%$, the trade flow of manufacturing sectors will decrease by $0,03 \%$, assuming all other variables remain constant. The two countries' exchange rate is the price level agreed upon by both countries' residents while trading. The exchange rate is distinguished by the nominal exchange rate and the real exchange rate. The nominal exchange rate is the relative price of the two countries' currencies, while the real exchange rate is related to the relative price of goods between the two countries. Mankiw (2009) states that the real exchange rate or trade shows one country's economic behavior in trading manufacturing sector products.

Moreover, he argues that the real exchange rate affects trade volume as it will be changed according to the relative price of goods and services traded. An increasing real exchange rate indicates a depreciation of the domestic currency, which will increase the value of exports. By increasing the real exchange rate, imported goods will be relatively 
more expensive than domestic goods. This condition causes the domestic market to reduce their imports and to increase their exports. Exchange rates can affect trade volume because exchange rates will change the relative price of goods and services being traded (Mankiw, 2009). A stable currency value indicates that the country has relatively good economic conditions (Salvatore, 2013). This study's results are consistent with the research conducted by Nicita (2013), which examines the exchange rate has an important role in trading performance determined by exogenous or policy shocks, the relative valuation of currency, and volatility.

Distance has a negative and significant effect on trade in the manufacturing sector with a distance coefficient of $-0,30$. If distance increases by $1 \%$, the manufacturing sector's trade flow will decrease by $0,30 \%$, assuming all other variables remain constant. This result is supported by Krugman (2000), who mentions that countries' distance is a determinant of international trade. He argues that the farther a country is from its trading partners, the higher the transportation costs borne by the involved countries (the country conducting the trading). Furthermore, this study is in line with the study conducted by Ülengin et al. (2015) on the influence of transportation quotas on textile trading between Turkey and the European Union. Turkey joined the customs union in 1996 and abolished import duties, but several European Union countries still have quotas on imports. The existence of a quota is against the customs union agreement. This caused Turkey to suffer losses because the number of Turkish textile exports to European Union countries decreased. Similarly, Chakravarty \& Chakrabarty (2014) find that the apt access between India and ASEAN countries (vice versa) open bigger market for Indian products in ASEAN countries.

This study's policy dummy variable is used to see the differences in the years before and after AFTA was enforced. The estimation results show that the policy dummy is positive and significant for manufacturing sector trade with a coefficient of 0,13 . It means that the policy dummy can show a trade difference of $13 \%$ [ $(\exp (0.11)$ $-1) * 100$ ] after the write-off policy rates are applied. The elimination of tariffs between member countries causes the market to become more expansive. Production costs fell so that economies of scale were larger than before. Trading costs are also reduced so that trade is increasing compared to before. This dummy indicates whether AFTA brings trade creation because it occurs when trade between members of a preferential trading arrangement replaces what would have been produced in the importing country were it not for the PTA.

The reduction of the tariff was also significantly affected the trade on ASEAN members' manufacture sector. Therefore, effective implementation of the AFTA CEPT scheme to reduce or eliminate tariff barriers may be expected to boost ASEAN members' trade. However, a greater number of products may need to be put on the CEPT inclusion list. This result is similar to Ekanayake et al. (2010), who state that regional trade cooperation has a creative impact on its member countries. Yang \& Zarzoso (2014) state that by tariff barriers, reduction and elimination can increase the trading rate value of its members (FTAs' countries) and the neighboring countries that have not or are not included in the FTAs.

Economic openness has a positive and significant effect on trade in the manufacturing sector with a coefficient of 0,93 . It means that if economic openness increases by $1 \%$, trade in the manufacturing sector will increase by $0,93 \%$, assuming all other variables remain constant.

Economic openness is an indicator to show the level of a country's exports and imports. The advantages of economic openness are (1) for a country with a relatively small domestic market, the potential for existing resources can still be processed for sale 
abroad; (2) economic openness will direct a country to productivity and production efficiency. It is what encourages the competitiveness of a country to improve its position in international trade. With this openness, the demand for imported goods increases, and the demand for goods decreases in response to changes in relative prices. In the short term, trade causes individuals to increase consumption so that demand is high. Economic openness is an indicator of the degree of economic relations between a country and another. The greater the value of economic openness will increase the degree of trade liberalization in the country. Increased trade impacts production efficiency, labor absorption, and decreased production costs to increase product competitiveness and ultimately increase ASEAN member countries.

In equation 2, GDP shows a positive and significant effect on FDI with a GDP coefficient of 1,28. It means that if GDP increases by $1 \%$, FDI will increase by $1,28 \%$, assuming all other variables remain constant.

The Harrod-Domar model explained the roles of investment in economic growth, namely: 1) investment has a role in increasing income and 2) investment can increase the production capacity of the economy by increasing the capital stock (Jhingan, 2011). According to the Neoclassical Solow Growth Theory, growth of the capital stock, labor force, and technological advances connects to the economy. It affects the GDP (the aggregate output produced by a country) (Mankiw, 2009). This result is also in line with endogenous growth theory, emphasizing capital accumulation in economic growth (Arsyad, 2010).

Foreign Direct Investment (FDI) becomes an important investment for developing countries because FDI allows local companies or manufacturing industries to obtain additional capital from foreign countries regarding technology and knowledge transfer and funding. It allows them to grow and results in increasing economic growth. Increasing economic growth indicates a big economic size and attracts foreign investment, which surely affects FDI. The size of the economy as a determinant of FDI is according to the theory of economic scale. The results of this study support the prior studies conducted by Rezac (2014); Sousa \& Lochard (2006); Stojkov \& Warin (2018); Biro et al. (2019), who mainly states that the bigger the size of an economy is, the higher the FDI increases.

The Real Effective Exchange Rate shows negative and significant effects on FDI with a REER coefficient of $-1,76$. It means that if the exchange rate increases by $1 \%$, FDI will decrease by $1,76 \%$, assuming all other variables remain constant. In terms of exchange rates, FDI serves as an investment in capital goods, land, and inventory. FDI is generally only carried out by multinational companies that manage natural resources and are engaged in export-oriented manufacturing and services. The effect of the exchange rate on FDI depends on the company's objectives. If investors purpose to export their products, the domestic currency depreciation will increase FDI due to increased product competitiveness. It happens because investment in that country is relatively cheaper than in other countries or even in the investors' countries. The real exchange rate stability also determines the amount of investment obtained by a country. This study supports the prior study conducted by Kahouli \& Omri (2017), who find that REER affects a country's trading.

Distance does not have any significant effect and is not by the theory. Transportation costs do not affect FDI because ASEAN member countries are free to invest with ASEAN Economic Community's implementation. FDI inflows are still dominated by ASEAN member countries, followed by Japan and other emerging market countries in Asia (including China). FDI provides an opportunity to reduce production costs while increasing market share. On the other hand, FDI is believed to benefit 
recipient countries, including economic growth, new capital inflows and technology, and increased employment. To attract FDI, each country takes different steps, depending on its characteristics, such as infrastructure, the trade regime adopted, the availability of skilled personnel, and institutions' quality.

The tariff elimination policy caused FDI to increase compared to before. One way of integrating investment into an economic regionalism model is to link discrimination in trade liberalization with relative factor remuneration changes. It is leading to changes in investment flows. Countries that are relatively abundant in the capital will experience a net inflow of investment with an increase in interest relative to wages. A relatively labor-abundant country will experience a net capital outflow due to decreased capital interest relative to wages-FTA or customs unions' effect on FDI location selection and its impacts on social welfare. Economic integration, through tariff reductions, will lead to greater FDI and hence, improve social welfare. FDI resulting from trade expansion is not necessarily beneficial to the host and/or home countries. There is some evidence that increased FDI due to trade enhancement leads to less competition in the domestic market and inadequate technology transfers. This study's results are from the research conducted by Sousa \& Lochard (2006) that economic integration lowers the transaction costs and adds Kox \& Rojas-Romagosa (2019). They find that FTA on Pacific Alliance positively influences foreign direct investment entries.

The analysis shows that economic openness (OPEN) has a significant positive effect on the manufacturing sector's trade flow by 0,93 . If economic openness (OPEN) increases by $1 \%$, trade flow in the manufacturing sector will increase $0.93 \%$, assuming all other variables remain constant. Whereas for FDI, OPEN has a significant positive effect with a significance value of 1.09 , which means that for every percent increase in economic openness (OPEN), there will be a $1.09 \%$ increase in its foreign direct investment (FDI).

Economic openness is an indicator to show the level of a country's exports and imports of the country concerned. This significance (in economic openness) impacts the increasing potential of overseas markets (in countries with small domestic markets) as well as increases the effectiveness, efficiency, and productivity of the manufacturing industry (in the domestic country). Apart from this, economic openness can boost the competitiveness of a country in the international trade arena. Economic openness brings in the opportunities for imports to meet the demand of goods from the domestic market due to a relatively low price (exchange rates) and opens up export opportunities for domestic goods to enter foreign markets. Economic openness is also an indication of the degree of economic relations among countries (one to another). The greater the value of economic openness, the higher the degree of trade liberalization from that country.

\section{CONCLUSIONS AND RECOMMENDATIONS}

\section{Conclusions}

Economic integration in the form of reduced import tariffs and trade openness increases trade and FDI volume. It is one of the pillars of establishing the ASEAN economic community, namely establishing ASEAN as a single market and based on a single production supported by elements of the free flow of goods, services, investment, educated labor, and freer capital flows. There is a similarity in the size of ASEAN member countries' economies, which tend to conduct trade and FDI with trading partner countries in ASEAN. Exchange rate stability is important for a country's economy. Fluctuating exchange rate movements will affect trade volume and FDI. Meanwhile, low transportation costs will increase trade and FDI in ASEAN countries. 


\section{Recommendations}

The ASEAN single market aims to create an integrated market among ASEAN member countries. The goal is to increase ASEAN's economic competitiveness as a product based on facing competition in world markets. It creates fierce competition in the ASEAN market and can increase competitiveness, so there needs to be a strategic policy to regulate this.

Governments in ASEAN countries make policies to create technology transfer and skill management between FDI-giving and receiving countries. Government policies in ASEAN countries to increase FDI to support infrastructure development and various other government policies such as FDI in strategic sectors and companies can provide optimal added value to improve ASEAN countries' economies.

\section{REFERENCES}

Agnosteva, D. E., Anderson, J. E., \& Yotov, Y. V. (2019). Intra-national trade costs: Assaying regional frictions. European Economic Review, 112, 32-50. https://doi.org/10.1016/j.euroecorev.2018.11.008

Anderson, J. E. (1979). A theoretical foundation for the gravity equation. The American Economic Review, 69(1), 106-116. https://www.jstor.org/stable/1802501

Arsyad, L. (2010). Ekonomi Pembangunan. (5th ed.). Yogyakarta: UPP STIM YKPM.

Baihaqi, R. (2018). Industri manufaktur Indonesia terbesar di ASEAN. Available at: https://economy.okezone.com/read/2018/02/12/320/1858169/industri-manufakturindonesia-terbesar-di-asean

Balassa B. (1994) The Theory of Economic Integration: An Introduction. In: Nelsen B.F., Stubb A.CG. (eds) The European Union (pp. 125-137). London: Palgrave. https://doi.org/10.1007/978-1-349-23984-9_15.

Baltagi. (2008). Econometric analysis of panel data. New Jersey: John Wiley and Sons.

Baltagi, B. H., \& Moscone, F. (2010). Health care expenditure and income in the OECD reconsidered: Evidence from panel data. Economic Modelling, 27(4), 804-811. https://doi.org/10.1016/j.econmod.2009.12.001

Biro, F. P., Erdey, L., Gall, J., \& Markus, A. (2019). The effect of governance on foreign direct investment in Latin America - issues of model selection. Global Economy Journal, 19(1). https://doi.org/10.1142/S2194565919500064

Chakravarty, S. L., \& Chakrabarty, R. (2014). A gravity model approach to IndoASEAN trade-fluctuations and swings. Procedia - Social and Behavioral Sciences, 133, 383-391. https://doi.org/10.1016/j.sbspro.2014.04.205

Damuri, Y. (2006). An evaluation of the need for selected trade facilitation measures in Indonesia: Implications for the WTO negotiations on trade facilitation. AsiaPacific Research and Training Network on Trade Working Paper Series, No. 10. Available at: https://www.unescap.org/sites/default/files/AWP No. 10.pdf

Effendi, Y. (2014). Implementasi ASEAN free trade agreement terkait Kinerja perdagangan Indonesia: Pendekatan model gravitasi. Buletin Ilmiah Litbang Perdagangan, 8(1), 1-22.

Ekanayake, E. M., Mukherjee, A., \& Veeramacheneni, B. (2010). Trade blocks and the gravity model: A study of economic integration among Asian developing countries. Journal of Economic Integration, 25(4), 627-643. https://doi.org/10.11130/jei.2010.25.4.627

Evenett, S. J., \& Keller, W. (2002). On theories explaining the success of the gravity equation. Journal of Political Economy, 110(2), 281-316. https://doi.org/https://doi.org/10.1086/338746

Frankel, J. A., \& Romer, D. (1999). Does trade cause growth? Journal of American 
Economic Review, 39(3), 379-399.

https://doi.org/10.1080/07448481.2018.1463228

Gujarati, D. (2015). Econometrics by examples ( $2^{\text {nd }}$ Edition). London: Red Globe Press

Helpman, E., \& Krugman, P. R. (1989). The impact of trade openness on economic growth: The case of Cote d'ivoire (3rd ed.). Massachusetts: The MITT Press.

Helpman, E., Melitz, M. J., \& Yeaple, S. R. (2004). Export versus FDI with heterogeneous firms. American Economic Review, 94(1), 300-316.

İncekara, A., \& Ustaoğlu, M. (2012). European Union's multilateralism on trade policies, custom unions and free trade agreements; comparative SWOT analyses of Turkey and South Korea's automotive industries. Procedia - Social and Behavioral Sciences, 58, 464-473. https://doi.org/10.1016/j.sbspro.2012.09.1023

Jhingan, M. L. (2011). The Economics of Development and Planning (40th ed.). Vrinda.

Kahouli, B., \& Omri, A. (2017). Foreign direct investment, foreign trade and environment: New evidence from simultaneous-equation system of gravity models. Research in International Business and Finance, 42, 353-364. https://doi.org/10.1016/j.ribaf.2017.07.161

Kawai, M., \& Naknoi, K. (2015). ASEAN economic integration through trade and foreign direct investment: Long-term challenges. ADBI Working Paper No. 545. Available at: https://www.adb.org/publications/asean-economic-integrationthrough-trade-and-foreign-direct-investment-long-term

Kepaptsoglou, K., Karlaftis, M. G., \& Tsamboulas, D. A. (2010). The gravity model specification for modeling international trade flows and free trade agreement effects: a 10-year review of empirical studies. The Open Economics Journal, 3, 113. https://doi.org/http://dx.doi.org/10.2174/1874919401003010001

Kox, H., \& Romagosa, H. R. (2019). Gravity estimations with FDI bilateral data: Potential FDI effects of deep preferential trade agreements. SSRN Electronic Journal (No. 70; Issue June). https://doi.org/10.2139/ssrn.3457319

Krugman, P., \& Obstfeld, M. (2003). International economics: Theory and policy (Sixth Ed). Elm Street Publishing Services, Inc. https://doi.org/10.4324/9780203462041

Mankiw, N. G. (2009). Macroeconomics (7 (ed.)). New York: Worth Publishers.

Nasrullah, M., Chang, L., Khan, K., Rizwanullah, M., Zulfiqar, F., \& Ishfaq, M. (2020). Determinants of forest product group trade by gravity model approach: A case study of China. Forest Policy and Economics, 113, 1-14. https://doi.org/10.1016/j.forpol.2020.102117

Nicita, A. (2013). Exchange rates, international trade and trade policies. International Economics, 135-136(56), 47-61. https://doi.org/10.1016/j.inteco.2013.10.003

Okabe, M. (2015). Impact of free trade agreements on trade in East Asia. ERIA Discussion Paper Series No. 32. Available at: https://www.econstor.eu/bitstream/10419/120420/1/804992568.pdf

Paulus, M., \& Michalíková, E. (2014). Gravity model analysis: Robust evidence from the Czech Republic and corruption matching. IES Working Paper No. 32/2014. Available at: https://www.econstor.eu/bitstream/10419/120420/1/804992568.pdf

Rezac, M. (2014). Determinants of foreign direct investment inflows to China: A Gravity Model Approach. [Bachelor thesis]. Charles University in Prague. Available at: https://is.cuni.cz/webapps/zzp/download/130123358

Ridhwan, M., Wicaksono, G., Nurliana, L., Bary, P., Suryani, T. \& Satyanugroho, R. (2015). Industri nasional di era masyarakat ekonomi ASEAN dan perdagangan bebas. Working Paper. Jakarta: Bank Indonesia

Salvatore, D. (2013). International economics (11th ed.). New Jersey: Wiley.

Samimi, P., \& Jenatabadi, H. (2014). Globalization and Economic Growth: Empirical 
Evidence on The Role of Complementarities. PLoS ONE, 9(4), 1-7. https://doi.org/10.1371/journal.pone.0087824

Silajdzic, S. \& Mehic, E. (2018). Trade openness and economic growth: Empirical evidence from transition economies. In V. Bobek (Ed.), Trade and Global Market. London: IntechOpen

Sousa, J. de, \& Lochard, J. (2011). Does the single currency affect FDI? A gravity-like approach. Journal of Economics, 113(3), 553-578. https://www.jstor.org/stable/23017117

Stojkov, A., \& Warin, T. (2018). EU membership and FDI: Is there an endogenous credibility effect? Journal of East-West Business, 24(3), 1-26. https://doi.org/10.1080/10669868.2018.1431579

Topalova, P. (2004). Trade liberalization and firm productivity: The case of India. IMF Working Papers, 04(28). Available at: https://doi.org/10.5089/9781451844696.001

Ugurlu, E., \& Jindrichovska, I. (2019). Estimating gravity model in the Czech Republic: Empirical study of impact of IFRS on Czech international trade. European Research Studies Journal, 22(2), 265-281. https://doi.org/10.35808/ersj/1438

Ülengin, F., Çekyay, B., Toktaş Palut, P., Ülengin, B., Kabak, Ö., Özaydin, Ö., \& Önsel Ekici, Ş. (2015). Effects of quotas on Turkish foreign trade: A gravity model. Transport Policy, 38, 1-7. https://doi.org/10.1016/j.tranpol.2014.09.006

Vahalík, B. (2014). Regional bilateral trade analysis of The European Union, China and ASEAN. Procedia Economics and Finance, 12, 709-717.

Wahyuningsih, D. (2011). Analisis perdagangan intra industri sektor manufaktur: Studi kasus ASEAN-5. Media Trend, 6(1), 23-32.

Yang, S., \& Zarzoso, I. M. (2014). A panel data analysis of trade creation and trade diversion effects: The case of ASEAN-China Free Trade Area. China Economic Review, 29, 138-151. https://doi.org/10.1016/j.chieco.2014.04.002

Yulisa, A. (2017). Analisis faktor-faktor yang mempengaruhi investasi langsung asing di Thailand. [Undergraduate Thesis]. Institut Pertanian Bogor. https://repository.ipb.ac.id/bitstream/handle/123456789/88863/H17ayu.pdf?seque nce $=1 \&$ isAllowed $=\mathrm{y}$

Zamroni. (2005). Analysis of intra-industry trade between Indonesia and Japan: A case study in manufactured and agricultural products. Economic and Finance in Indonesia, 53(1), 97-113. 